\title{
The combination of catechin, baicalin and $\beta$-caryophyllene potentially suppresses the production of inflammatory cytokines in mouse macrophages in vitro
}

\author{
MASAYOSHI YAMAGUCHI ${ }^{1}$ and ROBERT M. LEVY ${ }^{2}$ \\ ${ }^{1}$ Department of Pathology and Laboratory Medicine, David Geffen School of Medicine, \\ University of California, Los Angeles (UCLA), Los Angeles, CA 90095-1732; \\ ${ }^{2}$ Department of Clinical Development, Primus Pharmaceuticals, Inc., Scottsdale, AZ 85251, USA
}

Received October 24, 2018; Accepted March 18, 2019

DOI: $10.3892 /$ etm.2019.7452

\begin{abstract}
It has been demonstrated that the combination of three botanical factors of $(+)$-catechin, baicalin and $\beta$-caryophyllene, which exhibit anti-inflammatory effects, with comparatively lower concentrations of each factor, demonstrating a potent synergistic-suppressive effect on the growth of mouse macrophage RAW264.7 cells in vitro, and suggesting it may function as a pharmacologic tool for managing inflammatory diseases. The present study was undertaken to determine the suppressive effects of $(+)$-catechin, baicalin or $\beta$-caryophyllene on the production of inflammatory cytokines, including TNF- $\alpha$, IL- 6 and IL-1 $\beta$, which was enhanced by lipopolysaccharide (LPS) in RAW264.7 cells in vitro. The cells were cultured for 3 days without botanical factors, followed by incubation for $5 \mathrm{~h}$ in the presence of either vehicle, $(+)$-catechin $[1 \mu \mathrm{g} / \mathrm{ml}$ (3.45 $\mu \mathrm{M})]$, baicalin [1 $\mu \mathrm{g} / \mathrm{ml}(2.24 \mu \mathrm{M})]$, or $\beta$-caryophyllene $[1 \mu \mathrm{g} / \mathrm{ml}(5 \mu \mathrm{M})]$ with or without LPS $(100 \mathrm{ng} / \mathrm{ml})$; this $\mathrm{did}$ not have significant effects on the number of RAW264.7 cells. The production of TNF- $\alpha$, IL- 6 and IL- $1 \beta$ was not altered by the addition of (+)-catechin, baicalin, $\beta$-caryophyllene, or the three combined factors in RAW264.7 cells without LPS. LPS treatment caused a marked production of TNF- $\alpha$, IL-6, and IL-1 $\beta$. This enhancement was suppressed by the addition of $(+)$-catechin, baicalin or $\beta$-caryophyllene. Of note, the production of these cytokines was additively suppressed by the combination of the three factors in macrophages. Thus, the combination of $(+)$-catechin, baicalin and $\beta$-caryophyllene was found to reveal a potent suppressive effect on cytokine
\end{abstract}

Correspondence to: Dr Masayoshi Yamaguchi, Department of Pathology and Laboratory Medicine, David Geffen School of Medicine, University of California, Los Angeles (UCLA), 700 Tiverton Avenue, Los Angeles, CA 90095-1732, USA

E-mail: yamamasa11555@yahoo.co.jp

Key words: (+)-catechin, baicalin, $\beta$-caryophyllene, TNF- $\alpha$, IL-6, IL-1 $\beta$, macrophage, RAW264.7 cell production in macrophages in vitro. This composition may be a useful tool as a potent anti-inflammatory agent.

\section{Introduction}

Inflammation is a complex biological response of body tissues to harmful stimuli, such as pathogens, damaged cells or irritants; it is a protective response, involving immune cells, blood vessels, and molecular mediators (1). Inflammation may be cause of various diseases (1). The factors involved in the anti-inflammatory effect may play a therapeutic role for diseases implicated in inflammation. Anti-inflammatory effects have reportedly been exhibited by botanical factors, including catechin $(2,3)$, baicalin $(4,5)$, and $\beta$-caryophyllene (6,7). $\beta$-Caryophyllene, a sesquiterpene, is a natural dietary ingredient found in many edible plants, which can be ingested daily as an essential oil and is approved as a food additive by the Food and Drug Administration (FDA). Interestingly, $\beta$-caryophyllene is known to be a selective agonist of cannabinoid receptor type-2 and to exert cannabimimetic anti-inflammatory and analgesic effects in animals $(8,9)$ for both acute and chronic pain with inflammation (10-14). However, the mechanism by which $\beta$-caryophyllene exhibits anti-inflammatory effects is poorly understood. Previously, we investigated whether $\beta$-caryophyllene interacted with various botanical molecules, which revealed anti-inflammatory effects in mouse macrophages RAW264.7 cells in vitro (15). It was found that the combination of (+)-catechin, baicalin and $\beta$-caryophyllene with concentrations, which did not independently exhibit a significant effect on RAW264.7 cells, showed a synergistic-suppressive effect on the proliferation and a synergistic-stimulatory effect on the death of RAW267.4 cells in vitro (15), supporting the view that these three factors in combination could potentially eliminate activated macrophages. This may serve as a usefulness therapeutic tool against inflammation.

RAW264.7 cells are a murine macrophage that produces various inflammatory cytokines including TNF- $\alpha$, IL-6 and IL-1 $\beta$ (16). The present study was undertaken to investigate the suppressive effects of $(+)$-catechin, baicalin and $\beta$-caryophyllene, which does not have significant effects on 
cell number, on the production of inflammatory cytokines, including TNF- $\alpha$, IL-6 and IL-1 $\beta$, which is enhanced by the treatment with lipopolysaccharide (LPS) in mouse macrophage RAW264.7 cells in vitro. The productions of TNF- $\alpha$, IL- 6 and IL-1 $\beta$ was not altered by the addition of (+)-catechin, baicalin, $\beta$-caryophyllene or by the three combined factors in RAW264.7 cells cultured without LPS. The treatment with LPS caused a remarkable production of TNF- $\alpha$, IL- 6 and IL-1 $\beta$. This enhancement was suppressed by the addition of $(+)$-catechin, baicalin or $\beta$-caryophyllene. Interestingly, the production of these cytokines was suppressed in RAW264.7 cells by the combination of all three factors. Thus, the combination of $(+)$-catechin, baicalin and $\beta$-caryophyllene was found to have a potent-suppressive effect on macrophages in vitro. This composition may be a useful tool as anti-inflammatory agent.

\section{Materials and methods}

Materials. Dulbecco's modification of Eagle's medium (DMEM) with $4.5 \mathrm{~g} / 1$ glucose, L-glutamine and sodium pyruvate and antibiotics (penicillin and streptomycin) were purchased from Corning (Mediatech, Inc., Manassas, VA, USA). Fetal bovine serum (FBS) was from Hyclone (Logan, UT, USA). (+)-catechin, baicalin, and $\beta$-caryophyllene were obtained from Cayman Chemical (Ann Arbor, MI, USA). These reagents were dissolved in dimethylsulfoxide (DMSO) and stored in the dark at $-20^{\circ} \mathrm{C}$ until use experiment. All other reagents were purchased from Sigma-Aldrich (St. Louis, MO, USA) unless otherwise specified. We used the following doses: (+)-Catechin $[1 \mu \mathrm{g} / \mathrm{ml}(3.45 \mu \mathrm{M})$ of medium], baicalin $[1 \mu \mathrm{g} / \mathrm{ml}$ $(2.24 \mu \mathrm{M})]$, and $\beta$-caryophyllene $[1 \mu \mathrm{g} / \mathrm{ml}(5 \mu \mathrm{M})]$. At these doses, the combinations exhibited a synergistic effect on the number of RAW264.7 cells with culture for 3 days (15).

RAW264.7 cells. Mouse RAW264.7 cells (murine macrophage) were obtained from the American Type Culture Collection (Rockville, MD, USA) (17,18). RAW264.7 cells were cultured in DMEM containing $10 \% \mathrm{FBS}$ and $1 \% \mathrm{P} / \mathrm{S}$.

Assay of cell proliferation. To determine the effect of various factors on cell growth, RAW264.7 cells $\left(1 \times 10^{5} / \mathrm{ml}\right.$ per well) were cultured in a water-saturated atmosphere containing $5 \% \mathrm{CO}_{2}$ and $95 \%$ air at $37^{\circ} \mathrm{C}$ using a 24 -well plate $(8,19)$. Cells were cultured in DMEM containing 10\% FBS and $1 \% \mathrm{P} / \mathrm{S}$ in the presence of either vehicle $(1 \% \mathrm{DMSO}$ as a final concentration), (+)-catechin $(1 \mu \mathrm{g} / \mathrm{ml})$, baicalin $(1 \mu \mathrm{g} / \mathrm{ml})$, or $\beta$-caryophyllene $(1 \mu \mathrm{g} / \mathrm{ml})$ for 3 days upon reaching confluency. To determine the increase in cell number, RAW264.7 cells, which were attached on each dish, were then detached from each culture dish by adding a sterile solution $(0.1 \mathrm{ml}$ per well) of $0.05 \%$ trypsin plus EDTA in $\mathrm{Ca}^{2+} / \mathrm{Mg}^{2+}$-free PBS (Thermo Fisher Scientific, Inc., Waltham, MA, USA) with incubation for $2 \mathrm{~min}$ at $37^{\circ} \mathrm{C}$. Each well was then added $0.9 \mathrm{ml}$ of DMEM containing $10 \% \mathrm{FBS}$ and $1 \% \mathrm{P} / \mathrm{S}$. The cell number in the cell suspension was counted as described below in the section 'cell counting'.

Assay of cell death. To determine the effect of various factors on cell death including necrotic cell death and apoptotic cell death, RAW264.7 cells $\left(1 \times 10^{5} / \mathrm{ml}\right.$ per well) were cultured using a 24-well plate in DMEM containing 10\% FBS and $1 \% \mathrm{P} / \mathrm{S}$ for 3 days in reaching upon confluency in the absence of drugs $(8,20)$. After reaching on subconfluence with culture for 3 days, the cells were additionally cultured for $24 \mathrm{~h}$ after treatment of either vehicle (1\% DMSO as a final concentration), (+)-catechin $(1 \mu \mathrm{g} / \mathrm{ml}$ of medium), baicalin (1 $\mu \mathrm{g} / \mathrm{ml}), \beta$-caryophyllene $(1 \mu \mathrm{g} / \mathrm{ml})$, or their combination. After culture, the viable cells, which were attached on each dish, were detached from each culture dishes by adding a sterile solution $(0.1 \mathrm{ml}$ per well) of $0.05 \%$ trypsin plus EDTA in $\mathrm{Ca}^{2+} / \mathrm{Mg}^{2+}$-free PBS (Thermo Fisher Scientific, Inc.) with incubation for $2 \mathrm{~min}$ at $37^{\circ} \mathrm{C}$. Each well was then added $0.9 \mathrm{ml}$ of DMEM containing $10 \% \mathrm{FBS}$ and $1 \% \mathrm{P} / \mathrm{S}$. The cell number in the cell suspension was counted as described below in the section 'cell counting'.

Counting of cell number. To detach cells on each well after culturing in order to assay the proliferation and death of RAW264.7 cells, the culture dishes were incubated for $2 \mathrm{~min}$ at $37^{\circ} \mathrm{C}$ after the addition of a solution $(0.1 \mathrm{ml}$ per well $)$ containing $0.05 \%$ trypsin plus EDTA in $\mathrm{Ca}^{2+} / \mathrm{Mg}^{2+}$-free PBS, and the cells were detached through pipetting after the addition of DMEM (0.9 ml) containing 10\% FBS and 1\% P/S (8,19,20). Medium containing the suspended cells $(0.1 \mathrm{ml})$ was mixed by the addition of $0.1 \mathrm{ml}$ of $0.5 \%$ trypan blue staining solution, which can look living cells but not death cells. The number of viable cells was counted under a microscope (Olympus MTV-3) using a Hemocytometer (Sigma-Aldrich) and a cell counter (Line Seiki H-102P, Tokyo, Japan). For each dish, we took the average of two counts. Cell numbers are shown as number per well.

Assay of cytokine production. RAW264.7 cells (1x105/ml per well) were cultured in a 24 -well plate in DMEM containing $10 \% \mathrm{FBS}$ and $1 \% \mathrm{P} / \mathrm{S}$ for 3 days upon reaching subconfluency $(8,19)$, and then the cells were further cultured for $5 \mathrm{~h}$ after the addition of either vehicle (1\% DMSO as a final concentration), (+)-catechin (1 $\mu \mathrm{g} / \mathrm{ml}$ of medium), baicalin $(1 \mu \mathrm{g} / \mathrm{ml}),(\beta$-caryophyllene $(1 \mu \mathrm{g} / \mathrm{ml})$, or the three factors in combination ( $1 \mu \mathrm{g} / \mathrm{ml}$ of each factor) with or without LPS (100 ng/ ml). After incubation, medium was collected to assay cytokines, and then the cells were detached from each of the culture dishes to determine the number of cells as described in 'cell counting' (21). The concentrations of TNF- $\alpha$, IL-6 or IL-1 $\beta$ in the medium were analyzed with the ELISA kits (Thermo Fisher Scientific, Inc., Waltham, MA, USA) of mouse TNF- $\alpha$ (cat. no. KHC301), IL-6 (cat. no. EH2IL6), and IL-1 $\beta$ (cat. no. EM2IL1B) according to the manufactur's instructions. Data regarding the production of each cytokine are presented as pictogram (pg) secreted into culture medium (ml).

Statistical analysis. Data are presented as the mean \pm standard deviation (SD). Statistical significance was determined using GraphPad InStat version3 for Windows XP (GraphPad Software, Inc., La Jolla, CA, USA). Multiple comparisons were performed by one-way analysis of variance (ANOVA) with the Tukey-Kramer multiple comparisons post hoc test for parametric data as indicated, and we reanalyzed data without using t-tests. $\mathrm{P}<0.05$ was considered to indicate a statistically significant difference. 


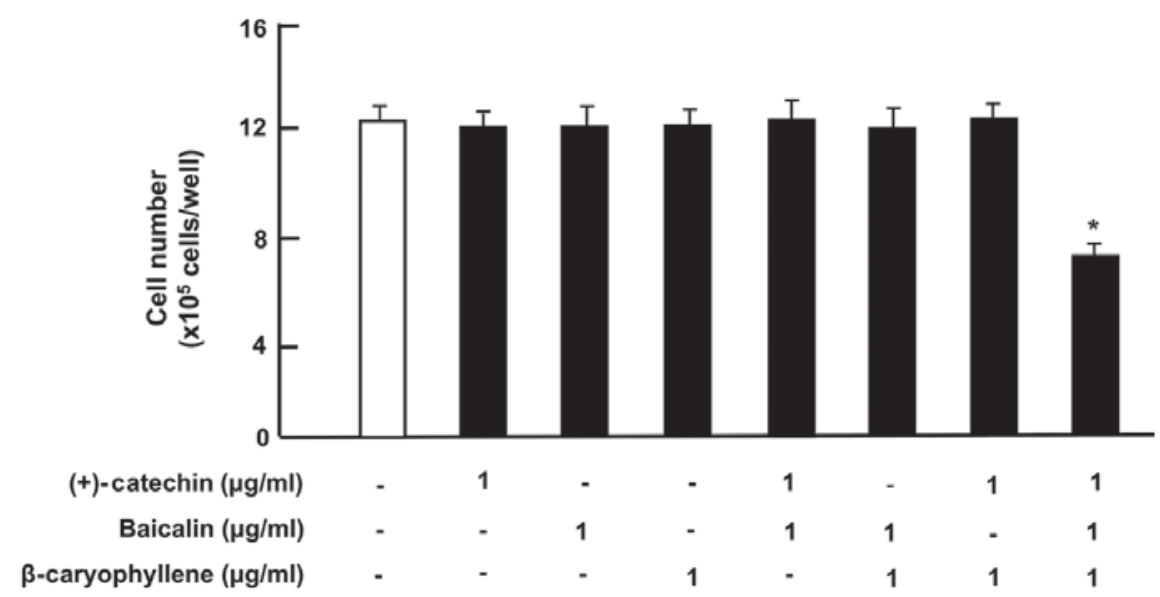

Figure 1. Effects of (+)-catechin, baicaline, and $\beta$-caryophylline on the proliferation of RAW264.7 cells in vitro. RAW264.7 cells (1x105/ml per well) were cultured for 3 days in DMEM containing either vehicle (1\% DMSO), (+)-catechin ( $1 \mu \mathrm{g} / \mathrm{ml}$ of medium), baicalin $(1 \mu \mathrm{g} / \mathrm{ml}), \beta$-caryophyllene $(1 \mu \mathrm{g} / \mathrm{ml})$, (+)-catechin $(1 \mu \mathrm{g} / \mathrm{ml}$ of medium) plus baicaline $(1 \mu \mathrm{g} / \mathrm{ml})$, or all three combined factors (each $1 \mu \mathrm{g} / \mathrm{ml})$. After culture, the number of attached cells on dish was counted. Data are presented as mean \pm SD obtained from 8 wells of 2 replicate wells per data set using different dishes and cell preparations. ${ }^{*} \mathrm{P}<0.001$ vs. control (white bar). One-way ANOVA, Tukey-Kramer post hoc test. DMEM, Dulbecco's modification of Eagle's medium; DMSO, dissolved in dimethylsulfoxide; SD, standard deviation.

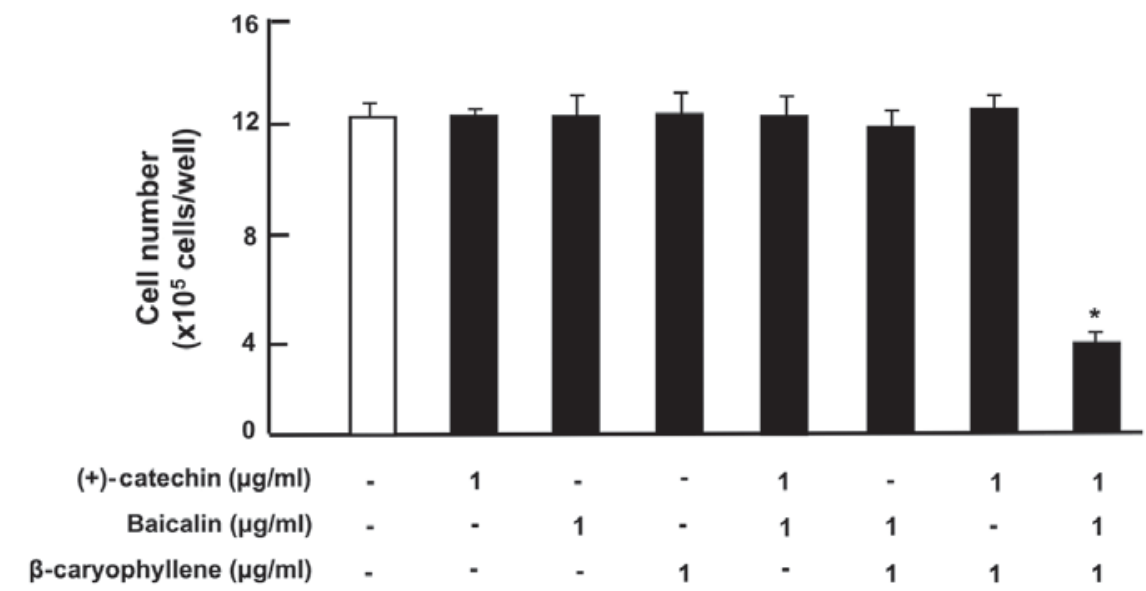

Figure 2. Effects of (+)-catechin, baicaline, and $\beta$-caryophylline on the death of RAW264.7 cells in vitro. RAW264.7 cells $\left(1 \times 10^{5} / \mathrm{ml}\right.$ per well) were cultured for 3 days in reaching upon subconfluence without botanical factors, and then were further cultured for $24 \mathrm{~h}$ in DMEM containing either vehicle, (+)-catechin $(1 \mu \mathrm{g} / \mathrm{ml})$, baicalin $(1 \mu \mathrm{g} / \mathrm{ml}), \beta$-caryophyllene $(1 \mu \mathrm{g} / \mathrm{ml}),(+)$-catechin $(1 \mu \mathrm{g} / \mathrm{ml})$ plus baicalin $(1 \mu \mathrm{g} / \mathrm{ml})$, baicalin $(1 \mu \mathrm{g} / \mathrm{ml})$ plus $\beta$-caryophyline $(1 \mu \mathrm{g} / \mathrm{ml})$, and catechin $(1 \mu \mathrm{g} / \mathrm{ml})$ plus $\beta$-caryophyline $(1 \mu \mathrm{g} / \mathrm{ml})$, or all three combined factors (each $1 \mu \mathrm{g} / \mathrm{ml})$. After culture, the number of attached cells on dish was counted. Data are presented as mean \pm SD obtained from 8 wells of 2 replicate wells per data set using different dishes and cell preparations. "P<0.001 vs. control (white bar). One-way ANOVA, Tukey-Kramer post hoc test. DMEM, Dulbecco's modification of Eagle's medium; SD, standard deviation.

\section{Results}

The effects of (+)-catechin, baicalin and $\beta$-caryophyllene, which have anti-inflammatory effects, on the proliferation of RAW264.7 cells in vitro were investigated. To determine the effect on cell proliferation, RAW264.7 cells were cultured for 3 days in the presence of either vehicle (1\% DMSO as a final concentration), (+)-catechin $[1 \mu \mathrm{g} / \mathrm{ml}(3.45 \mu \mathrm{M})]$, baicalin $[1 \mu \mathrm{g} / \mathrm{ml}(2.24 \mu \mathrm{M})]$, or $\beta$-caryophyllene $[1 \mu \mathrm{g} / \mathrm{ml}(5 \mu \mathrm{M})]$ (Fig. 1). Cell growth was not altered in the presence of (+)-catechin, baicalin, $\beta$-caryophyllene, or baicalin $(1 \mu \mathrm{g} / \mathrm{ml})$ plus $\beta$-caryophyline $(1 \mu \mathrm{g} / \mathrm{ml})$, and catechin $(1 \mu \mathrm{g} / \mathrm{ml})$ plus $\beta$-caryophyline $(1 \mu \mathrm{g} / \mathrm{ml})$. Of note, the three combination of $(+)$-catechin, baicalin and $\beta$-caryophyllene revealed a potential-suppressive effect on cell proliferation (Fig. 1). Suppression of cell proliferation caused during 3 days-culture with combined compounds showed approximately $45 \%$ as compared with that of control.

Next, to determine the effects of (+)-catechin, baicalin or $\beta$-caryophyllene on the death of RAW264.7 cells, the cells were cultured for 3 days in the absence of botanical factors, and then the cells were cultured for an additional $24 \mathrm{~h}$ in the presence of either vehicle (1\% DMSO as a final concentration), (+)-catechin $(1 \mu \mathrm{g} / \mathrm{ml})$, baicalin $(1 \mu \mathrm{g} / \mathrm{ml})$, or $\beta$-caryophyllene $(1 \mu \mathrm{g} / \mathrm{ml})$. The numbers of cells were not changed by the addition of each factor (Fig. 2). Of note, the combination of (+)-catechin, baicalin and $\beta$-caryophyllene exhibited a potential-stimulatory effect on cell death (including necrotic cell death and apoptotic cell death) (Fig. 2). Further experiment may be used to determine a specific apoptotic cell death. Result showed the reduction of cell number approximately $60 \%$ with the three combined drugs as compared with that of control. Thus, the combination of 
A

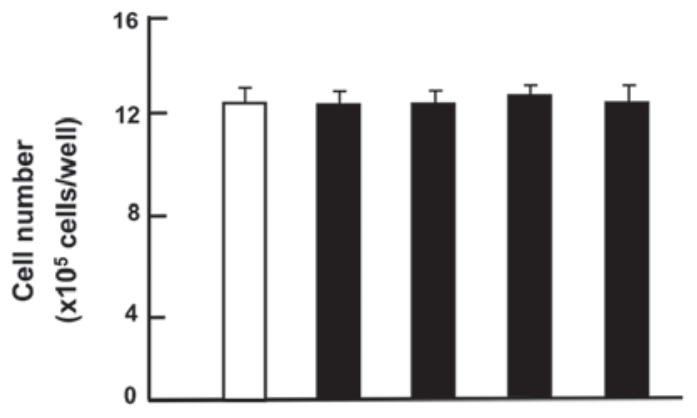

$\begin{array}{rrrrrr}(+) \text {-catechin }(\mu \mathrm{g} / \mathrm{ml}) & - & 1 & - & - & 1 \\ \text { Baicalin }(\mu \mathrm{g} / \mathrm{ml}) & - & - & 1 & - & 1 \\ \beta \text {-caryophyllene }(\mu \mathrm{g} / \mathrm{ml}) & - & - & - & 1 & 1\end{array}$
B

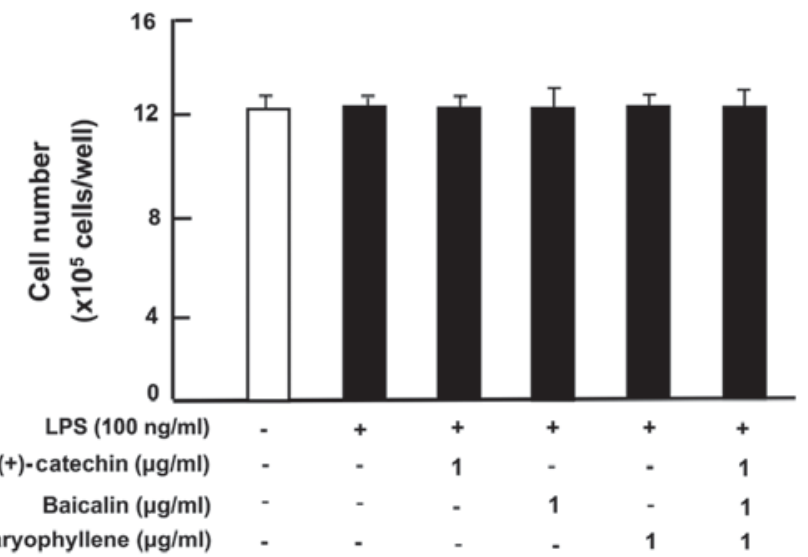

Figure 3. Effects of (+)-catechin, baicaline, and $\beta$-caryophylline on the number of RAW264.7 cells with or without LPS stimulation. RAW264.7 cells (1x10 $/ \mathrm{ml}$ per well) were cultured in the absence of botanical factors for 3 days in reaching upon subconfluence, and then the cells were further incubated for $5 \mathrm{~h}$ after the addition of either vehicle (1\% DMSO), (+)-catechin $(1 \mu \mathrm{g} / \mathrm{ml})$, baicalin $(1 \mu \mathrm{g} / \mathrm{ml}), \beta$-caryophyllene $(1 \mu \mathrm{g} / \mathrm{ml})$, or all three combined factors (each $1 \mu \mathrm{g} / \mathrm{ml})$ without (A) or with (B) LPS (100 ng/ml). After incubation, the number of attached cells on dish was counted. Data are presented as mean \pm SD obtained from 8 wells of 2 replicate wells per data set using different dishes and cell preparations. One-way ANOVA, Tukey-Kramer post hoc test. LPS, lipopolysaccharide; DMSO, dissolved in dimethylsulfoxide; SD, standard deviation.

A

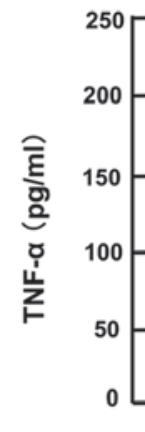

$(+)$-catechin $(\mu \mathrm{g} / \mathrm{ml})$

Baicalin $(\mu \mathrm{g} / \mathrm{ml})$

$\beta$-caryophyllene $(\mu \mathrm{g} / \mathrm{ml})$

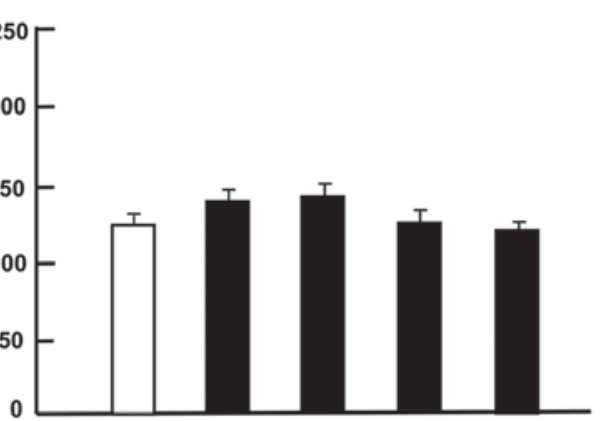

$-1$

$-1$

11
B

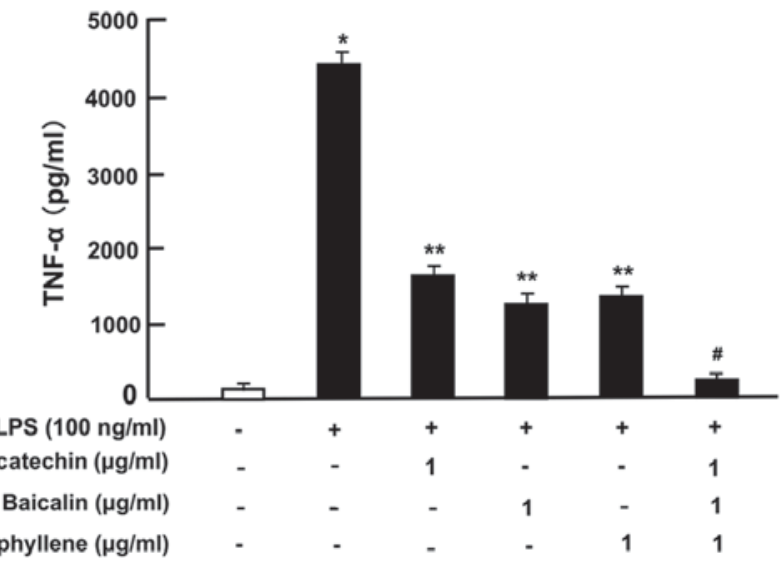

Figure 4. Effects of (+)-catechin, baicaline, and $\beta$-caryophylline on the production of TNF- $\alpha$ with LPS stimulation in RAW264.7 cells. Cells (1x10 $/ \mathrm{ml}$ per well) were cultured in the absence of botanical factors for 3 days in reaching on subconfluence, and then were further incubated for $5 \mathrm{~h}$ after the addition of either vehicle (1\% DMSO), (+)-catechin $(1 \mu \mathrm{g} / \mathrm{ml})$, baicalin $(1 \mu \mathrm{g} / \mathrm{ml}), \beta$-caryophyllene $(1 \mu \mathrm{g} / \mathrm{ml})$, or all three combined factors (each $1 \mu \mathrm{g} / \mathrm{ml})$ without $(\mathrm{A})$ or with (B) LPS $(100 \mathrm{ng} / \mathrm{ml})$. After incubation, the medium was collected, and TNF- $\alpha$ concentration in the mediun was determined. Data are presented as mean \pm SD obtained from 8 wells of 2 replicate wells per data set using different dishes and cell preparations. ${ }^{*} \mathrm{P}<0.001$ vs. control (white bar); ${ }^{* *} \mathrm{P}<0.001$ vs. LPS (black bar); ${ }^{\#} \mathrm{P}<0.001$ vs. LPS plus either (+)-catechin, baicalin, or $\beta$-caryophyllene. One-way ANOVA, Tukey-Kramer post hoc test. LPS, lipopolysaccharide; DMSO, dissolved in dimethylsulfoxide; SD, standard deviation.

(+)-catechin, baicalin and $\beta$-caryophyllene was demonstrated to reveal potential effects on the depression of proliferation and the stimulation of death in mouse macrophage RAW264.7 cells, leading to the reduction of macrophage related to inflammation.

Moreover, we investigated the effects of $(+)$-catechin, baicalin or $\beta$-caryophyllene on the production of inflammatory cytokines, including TNF- $\alpha$, IL-6 and IL-1 $\beta$, in RAW264.7 cells. In the previous studies (15), we investigated the effect of increasing dosages of the used three botanical factors in the range of 0.1 to $100 \mu \mathrm{g} / \mathrm{ml}$ of medium in RAW264.7 cells in vitro. Potential-suppressive effect on the number of cells was found in over $1 \mu \mathrm{g} / \mathrm{ml}$ of each factor, which were based on our previous finding. Cytokine production by cells was resulted from the number of living cell on the dish. Therefore, it was important to estimate cytokine production with the use of chemical dosage, which did not have any effects on cell number. In this experiment, the cells were cultured for 3 days without botanical factors, and the cells, upon reaching subconfluency, were cultured for an additional $5 \mathrm{~h}$ in the presence of either vehicle, $(+)$-catechin $(1 \mu \mathrm{g} / \mathrm{ml})$, baicalin $(1 \mu \mathrm{g} / \mathrm{ml}), \beta$-caryophyllene $(1 \mu \mathrm{g} / \mathrm{ml})$, or three combined factors with or without LPS (100 ng/ml). The number of RAW264.7 cells was not changed by the culture with (+)-catechin, baicalin, $\beta$-caryophyllene, or a combination of the three factors in the presence (Fig. 3A) or absence (Fig. 3B) of LPS.

Then, under culture conditions that did not alter the cell number, we determined the effects of $(+)$-catechin, baicalin, $\beta$-caryophyllene, or three combined factors on the production of TNF- $\alpha$, IL-6, and IL-1 $\beta$ in RAW264.7 cells incubated with or without LPS (100 ng/ml). In the absence of LPS, the productions of TNF- $\alpha$ (Fig. 4A), IL-6 (Fig. 5A) and IL-1 $\beta$ 
A

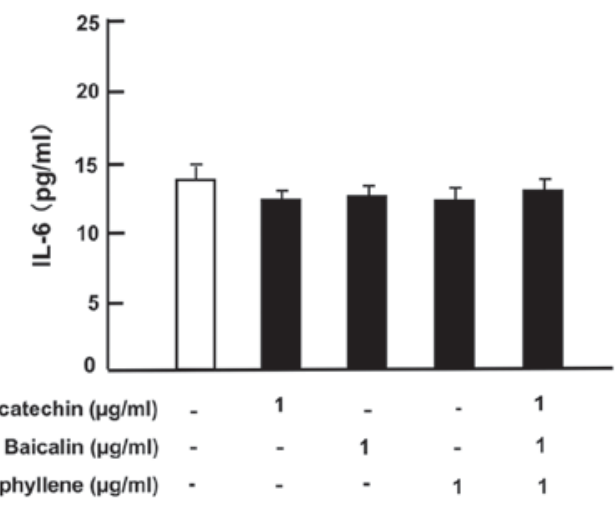

B

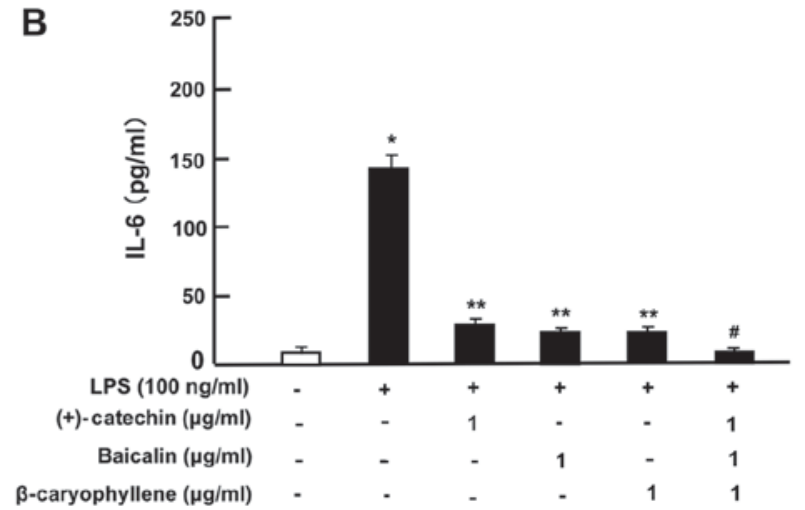

Figure 5. Effects of (+)-catechin, baicaline, and $\beta$-caryophylline on the production of IL-6 with LPS stimulation in RAW264.7 cells. Cells (1x105/ml per well) were cultured in the absence of botanical factors for 3 days in reaching on subconfluence, and then were further incubated for $5 \mathrm{~h}$ after the addition of either vehicle (1\% DMSO), (+)-catechin $(1 \mu \mathrm{g} / \mathrm{ml})$, baicalin $(1 \mu \mathrm{g} / \mathrm{ml}), \beta$-caryophyllene $(1 \mu \mathrm{g} / \mathrm{ml})$, or all three combined factors (each $1 \mu \mathrm{g} / \mathrm{ml})$ without (A) or with (B) LPS $(100 \mathrm{ng} / \mathrm{ml})$. After incubation, the medium was collected, and IL-6 concentration in the mediun was determined. Data are presented as mean \pm SD obtained from 8 wells of 2 replicate wells per data set using different dishes and cell preparations. ${ }^{*} \mathrm{P}<0.001$ vs. control (white bar); ${ }^{* *} \mathrm{P}<0.001$ vs. LPS (black bar); ${ }^{*} \mathrm{P}<0.001$ vs. LPS plus either (+)-catechin, baicalin, or $\beta$-caryophyllene. One-way ANOVA, Tukey-Kramer post hoc test. LPS, lipopolysaccharide; DMSO, dissolved in dimethylsulfoxide; SD, standard deviation.

A

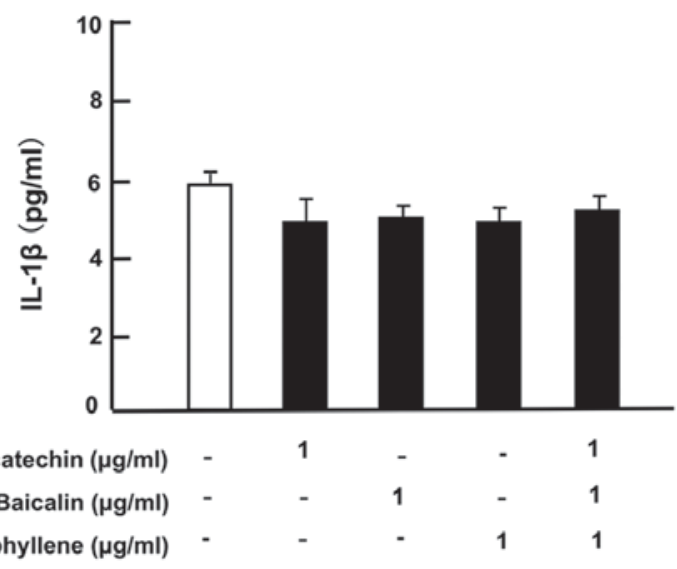

B

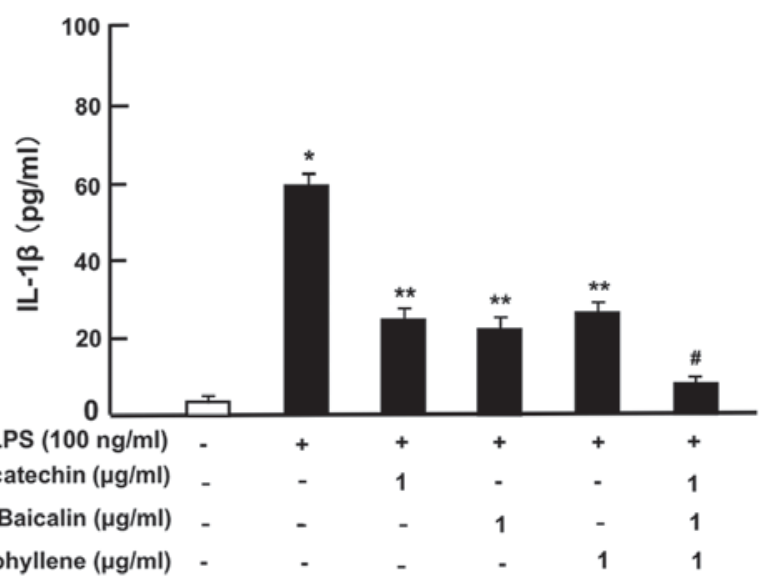

Figure 6. Effects of (+)-catechin, baicaline, and $\beta$-caryophylline on the production of IL-1 $\beta$ with LPS stimulation in RAW264.7 cells. Cells (1x105/ml per well) were cultured in the absence of botanical factors for 3 days in reaching on subconfluence, and then were further incubated for $5 \mathrm{~h}$ after the addition of either vehicle (1\% DMSO), (+)-catechin $(1 \mu \mathrm{g} / \mathrm{ml})$, baicalin $(1 \mu \mathrm{g} / \mathrm{ml}), \beta$-caryophyllene $(1 \mu \mathrm{g} / \mathrm{ml})$, or all three combined factors (each $1 \mu \mathrm{g} / \mathrm{ml})$ without (A) or with (B) LPS $(100 \mathrm{ng} / \mathrm{ml})$. After incubation, the medium was collected, and IL-1 $\beta$ concentration in the mediun was determined. Data are presented as mean \pm SD obtained from 8 wells of 2 replicate wells per data set using different dishes and cell preparations. ${ }^{*} \mathrm{P}<0.001$ vs. control (white bar); ${ }^{* *} \mathrm{P}<0.001 \mathrm{vs}$. LPS (black bar); ${ }^{*} \mathrm{P}<0.001$ vs. LPS plus either (+)-catechin, baicalin, or $\beta$-caryophyllene. One-way ANOVA, Tukey-Kramer post hoc test. LPS, lipopolysaccharide; DMSO, dissolved in dimethylsulfoxide; SD, standard deviation.

(Fig. 6A) was not significantly altered by the addition of (+)-catechin $(1 \mu \mathrm{g} / \mathrm{ml})$, baicalin $(1 \mu \mathrm{g} / \mathrm{ml}), \beta$-caryophyllene $(1 \mu \mathrm{g} / \mathrm{ml})$, or their combination in RAW264.7 cells. Treatment with LPS caused a marked production of TNF- $\alpha$ (Fig. 4B), IL-6 (Fig. 5B), or IL-1 $\beta$ (Fig. 6B). These elevations were suppressed by the addition of $(+)$-catechin $(1 \mu \mathrm{g} / \mathrm{ml})$, baicalin $(1 \mu \mathrm{g} / \mathrm{ml})$, or $\beta$-caryophyllene $(1 \mu \mathrm{g} / \mathrm{ml})$. Interestingly, the combination of all three factors caused a potential-suppressive effect on the production of TNF- $\alpha$ (Fig. 4B), IL-6 (Fig. 5B), and IL-1 $\beta$ (Fig. 6B).

\section{Discussion}

Current study was investigated to determine the effects of the combination of (+)-catechin, baicalin and $\beta$-caryophyllene, which reveal anti-inflammatory effects, on the proliferation and death and the production of inflammatory cytokines in mouse macrophage RAW264.7 cells in vitro. The growth of cells was not altered in the presence of (+)-catechin, baicalin, and $\beta$-caryophyllene. Of note, the three combined factors were demonstrated to exhibit a potential-suppressive effect on the proliferation and a potential -stimulatory effect on the death of RAW264.7 cells in vitro. Current results confirmed our previous findings that the three combination of (+)-catechin, baicalin and $\beta$-caryophyllene reveals synergistic effects on the reduction of the number of mouse macrophage RAW264.7 cells (15), leading to the elimination of macrophage related to inflammation.

Moreover, we investigated whether the combination of (+)-catechin, baicalin and $\beta$-caryophyllene potently suppressed the production of inflammatory cytokines, including TNF- $\alpha$, IL-1 $\beta$ and IL-6, under short-culture conditions, which did not 
reveal suppressive effects on cell number with each factor alone or three combined molecules (Fig. 2). Of note, the combination of $(+)$-catechin, baicalin and $\beta$-caryophyllene was found to exhibit an additive-depressive effect on the production of cytokines as compared with that of each factor alone. This result suggests that three combined factors have a potential-suppressive effect on the production of cytokines involved in inflammation. It is assumed that the three combined factors suppress the production of inflammatory cytokines in a short culture period, and this leads to a reduction in the number of macrophages with longer culture in vitro.

In a previous study, in which RAW264.7 cells were cultured with the combination of $(+)$-catechin, baicalin and $\beta$-caryophyllen for 3 days, we demonstrated that the combined three factors induced $\mathrm{G} 2 / \mathrm{M}$ phase cell cycle arrest in the proliferation of RAW264.7 cells using various inhibitors related to cell-cycle arrest in vitro (15). The suppressive effects on cell proliferation of three combined botanical factors were suggested to link to inhibiting manifold intracellular signaling pathways, which are related to signaling pathways of PI3/Akt, ERK/MAPK, and $\mathrm{Ca}^{2+}$ in RAW264.7 cells, using various inhibitors $(8,22-25)$. Moreover, three combined factors were demonstrated to decrease the protein levels of Akt and MAPKs (p44/42 and p38) in RAW264.7 cells. The stimulatory effects of three combined botanical molecules on cell death were related to the activation of caspase-3 (15), which activates nuclear DNA fragmentation and induces apoptotic cell death (26).

In the current study, RAW264.7 cells, upon reaching subconfluency, were cultured for $5 \mathrm{~h}$ after the treatment with the combination of $(+)$-catechin, baicalin and $\beta$-caryophyllen, the number of cells was not altered with these combinations. Of note, the productions of cytokines with LPS activation was demonstrated to potentially be suppressed by the treatment with three factors in combination in RAW264.7 cells. The combination of $(+)$-catechin, baicalin and $\beta$-caryophyllene was showed to decrease COX-1 and COX-2 in RAW264.7 cells in vitro (15). Inflammation-inducing factors are reported to increase COX-2 and NF- $\kappa \mathrm{B}$ p65, which is associated with the mitogen-activated protein kinase (MAPK)-signaling pathways (27-30). In addition, TNF- $\alpha$-enhanced COX-2 and $\mathrm{NF}-\kappa \mathrm{B}$ p65 levels were suppressed by culture with these three botanical molecules in combination (15). LPS treatment has been reported to enhance the production of TNF- $\alpha$, IL- 6 and IL-1 $\beta$ due to stimulating signaling pathways linked to MAPK and NF- $\kappa \mathrm{B}$ p65 in macrophage RAW264.7 cells (31-33). It is possible that the combination of $(+)$-catechin, baicalin and $\beta$-caryophyllene may exhibit potent suppressive effects on the LPS-enhanced production of inflammatory cytokines by inhibiting signaling pathways involved in MAPK and NF- $\mathrm{BB}$ p65 in the activated macrophages. However, this remains to be elucidated.

In conclusion, the present study demonstrates that the LPS-enhanced production of inflammatory cytokines in mouse macrophage RAW264.7 cells is potentially suppressed by the treatment with the combination of $(+)$-catechin, baicalin and $\beta$-caryophyllene with comparatively low levels, which did not show any effects on the number of RAW264.7 cells. This combination may be a useful anti-inflammatory therapeutic tool.

\section{Acknowledgements}

Not applicable.

\section{Funding}

No funding was received.

\section{Availability of data and materials}

The datasets used during the present study are available from the corresponding author upon reasonable request.

\section{Authors' contributions}

MY conceived and designed the study, and performed the experiment. MY and RL discussed the findings and interpreted the results. MY wrote the manuscript, and RL reviewed and edited the manuscript. All authors read and approved the manuscript and agree to be accountable for all aspects of the research in ensuring that the accuracy or integrity of any part of the study are appropriately investigated and resolved.

\section{Ethics approval and consent to participate}

Not applicable.

\section{Patient consent for publication}

Not applicable.

\section{Competing interests}

The authors declare that they have no competing interests.

\section{References}

1. Villanueva-Romero R, Gutiérrez-Cañas I, Carrión M, Pérez García S, Seoane IV, Martínez C, Gomariz RP and Juarranz Y: The anti-inflammatory mediator, vasoactive intestinal peptide, modulates the differentiation and function of Th subsets in rheumatoid arthritis. J Immunol Res 2018: 6043710, 2018

2. Kalaiselvi P, Rajashree K, Bharathi Priya L and Padma VV: Cytoprotective effect of epigallocatechin-3-gallate against deoxynivalenol-induced toxicity through anti-oxidative and anti-inflammatory mechanisms in HT-29 cells. Food Chem Toxicol 56: 110-118, 2013.

3. Morrison M, van der Heijden R, Heeringa P, Kaijzel E, Verschuren L, Blomhoff R, Kooistra T and Kleemann R: Epicatechin attenuates atherosclerosis and exerts anti-inflammatory effects on diet-induced human-CRP and $\mathrm{NF \kappa B}$ in vivo. Atherosclerosis 233: 149-156, 2014.

4. Qian Y, Chen Y, Wang L and Tou J: Effects of baicalin on inflammatory reaction, oxidative stress and PKDl and NF-kB protein expressions in rats with severe acute pancreatitis1. Acta Cir Bras 33: 556-564, 2018.

5. Bitto A, Squadrito F, Irrera N, Pizzino G, Pallio G, Mecchio A, Galfo F and Altavilla D: Flavocoxid, a nutraceutical approach to blunt inflammatory conditions. Mediators Inflamm 2014: 790851, 2014.

6. Sharma C, Al Kaabi JM, Nurulain SM, Goyal SN, Kamal MA and Ojha S: Polypharmacological properties and therapeutic potential of $\beta$-caryophyllene: a dietary phytocannabinoid of pharmaceutical promise. Curr Pharm Des 22: 3237-3264, 2016. 
7. Klauke AL, Racz I, Pradier B, Markert A, Zimmer AM, Gertsch J and Zimmer A: The cannabinoid $\mathrm{CB}_{2}$ receptor-selective phytocannabinoid beta-caryophyllene exerts analgesic effects in mouse models of inflammatory and neuropathic pain. Eur Neuropsychopharmacol 24: 608-620, 2014.

8. Gertsch J, Leonti M, Raduner S, Racz I, Chen JZ, Xie XQ, Altmann KH, Karsak M, Zimmer A and Zimmer A Beta-caryophyllene is a dietary cannabinoid. Proc Natl Acad Sci USA 105: 9099-9104, 2008.

9. Ormeño E, Baldy V, Ballini C and Fernandez C: Production and diversity of volatile terpenes from plants on calcareous and siliceous soils: effect of soil nutrients. J Chem Ecol 34: 1219-1229, 2008.

10. Katsuyama S, Mizoguchi H, Kuwahata H, Komatsu T, Nagaoka K, Nakamura H, Bagetta G, Sakurada T and Sakurada S: Involvement of peripheral cannabinoid and opioid receptors in $\beta$-caryophyllene-induced antinociception. Eur J Pain 17: 664-675, 2013.

11. Paula-Freire LI, Andersen ML, Gama VS, Molska GR and Carlini EL: The oral administration of trans-caryophyllene attenuates acute and chronic pain in mice. Phytomedicine 21: 356-362, 2014

12. Chavan MJ, Wakte PS and Shinde DB: Analgesic and anti-inflammatory activity of Caryophyllene oxide from Annona squamosa L. bark. Phytomedicine 17: 149-151, 2010.

13. Ghelardini C, Galeotti N, Di Cesare Mannelli L, Mazzanti G and Bartolini A: Local anaesthetic activity of beta-caryophyllene. Farmaco 56: 387-389, 2001.

14. Martinez RM, Zarpelon AC, Cardoso RD, Vicentini FT, Georgetti SR, Baracat MM, Andrei CC, Moreira IC, Verri WA Jr and Casagrande R: Tephrosia sinapou ethyl acetate extract inhibits inflammatory pain in mice: Opioid receptor dependent inhibition of TNF $\alpha$ and IL-1 $\beta$ production. Pharm Biol 51: 1262-1271, 2013

15. Yamaguchi M and Levy RM: The combination of $\beta$-caryophyllene, baicalin and catechin synergistically suppresses the proliferation and promotes the death of RAW267.4 macrophages in vitro. Int J Mol Med 38: 1940-1946, 2016

16. Pomari E, Stefanon B and Colitti M: Effect of plant extracts on $\mathrm{H} 2 \mathrm{O} 2$-induced inflammatory gene expression in macrophages. J Inflamm Res 7: 103-112, 2014.

17. Yamaguchi M, Vikulina T, Arbiser JL and Weitzmann MN: Suppression of NF- $\kappa \mathrm{B}$ activation by gentian violet promotes osteoblastogenesis and suppresses osteoclastogenesis. Curr Mol Med 14: 783-792, 2014.

18. Yamaguchi M and Weitzmann MN: The bone anabolic carotenoid p-hydroxycinnamic acid promotes osteoblast mineralization and suppresses osteoclast differentiation by antagonizing NF- $\mathrm{B}$ activation. Int J Mol Med 30: 708-712, 2012.

19. Yamaguchi $\mathrm{M}$ and Daimon Y: Overexpression of regucalcin suppresses cell proliferation in cloned rat hepatoma H4-II-E cells: involvement of intracellular signaling factors and cell cycle-related genes. J Cell Biochem 95: 1169-1177, 2005.

20. Izumi T and Yamaguchi M: Overexpression of regucalcin suppresses cell death in cloned rat hepatoma H4-II-E cells induced by tumor necrosis factor-alpha or thapsigargin. J Cell Biochem 92: 296-306, 2004.
21. Okuno T, Gijón MA, Zarini S, Martin SA, Barkley RM, Johnson CA, Ohba M, Yokomizo T and Murphy RC: Altered eicosanoid production and phospholipid remodeling during cell culture. J Lipid Res 59: 542-549, 2018

22. Meijer L, Borgne A, Mulner O, Chong JP, Blow JJ, Inagaki N, Inagaki M, Delcros JG and Moulinoux JP: Biochemical and cellular effects of roscovitine, a potent and selective inhibitor of the cyclin-dependent kinases cdc2, cdk2 and cdk5. Eur J Biochem 243: 527-536, 1997.

23. Singh SV, Herman-Antosiewicz A, Singh AV, Lew KL, Srivastava SK, Kamath R, Brown KD, Zhang L and Baskaran R: Sulforaphane-induced G2/M phase cell cycle arrest involves checkpoint kinase 2-mediated phosphorylation of cell division cycle 25C. J Biol Chem 279: 25813-25822, 2004.

24. Serrano-Nascimento C, da Silva Teixeira S, Nicola JP, Nachbar RT, Masini-Repiso AM and Nunes MT: The acute inhibitory effect of iodide excess on sodium/iodide symporter expression and activity involves the PI3K/Akt signaling pathway. Endocrinology 155: 1145-1156, 2014

25. Chen S, Wang Y, Ruan W, Wang X and Pan C: Reversing multidrug resistance in hepatocellular carcinoma cells by inhibiting extracellular signal-regulated kinase/mitogen-activated protein kinase signaling pathway activity. Oncol Lett 8: 2333-2339, 2014.

26. Zhao Y, Jing Z, Li Y and Mao W: Berberine in combination with cisplatin suppresses breast cancer cell growth through induction of DNA breaks and caspase-3-dependent apoptosis. Oncol Rep 36: 567-572, 2016.

27. Echizen K, Hirose O, Maeda Y and Oshima M: Inflammation in gastric cancer: interplay of the COX-2/prostaglandin E2 and Toll-like receptor/MyD88 pathways. Cancer Sci 107: 391-397, 2016.

28. Lin CC, Chan CM, Huang YP, Hsu SH, Huang CL and Tsai SJ: Methylglyoxal activates $\mathrm{NF}-\kappa \mathrm{B}$ nuclear translocation and induces COX-2 expression via a p38-dependent pathway in synovial cells. Life Sci 149: 25-33, 2016.

29. Li N, Liu BW, Ren WZ, Liu JX, Li SN, Fu SP, Zeng YL, Xu SY, Yan X, Gao YJ, et al: GLP-2 attenuates LPS-induced inflammation in BV-2 cells by inhibiting ERK1/2, JNK1/2 and NF- $\mathrm{BB}$ signaling pathway. Int J Mol Sci 17: 190, 2016.

30. Cha SM, Cha JD, Jang EJ, Kim GU and Lee KY: Sophoraflavanone G prevents Streptococcus mutans surface antigen I/II-induced production of NO and PGE2 by inhibiting MAPK-mediated pathways in RAW 264.7 macrophages. Arch Oral Biol 68: 97-104, 2016

31. Xu X, Yin P, Wan C, Chong X, Liu M, Cheng P, Chen J, Liu F and $\mathrm{Xu} \mathrm{J}$ : Punicalagin inhibits inflammation in LPS-induced RAW264.7 macrophages via the suppression of TLR4-mediated MAPKs and NF- $\mathrm{B}$ activation. Inflammation 37: 956-965, 2014

32. Cho BO, So Y, Jin CH, Nam BM, Yee ST and Jeong IY: 3-deoxysilybin exerts anti-inflammatory effects by suppressing NF- $\kappa \mathrm{B}$ activation in lipopolysaccharide-stimulated RAW264.7 macrophages. Biosci Biotechnol Biochem 78: 2051-2058, 2014.

33. Zhao G, Zhang T, Ma X, Jiang K, Wu H, Qiu C, Guo M and Deng G: Oridonin attenuates the release of pro-inflammatory cytokines in lipopolysaccharide-induced RAW264.7 cells and acute lung injury. Oncotarget 8: 68153-68164, 2017. 